\title{
STRATEGI SEKOLAH DALAM MENERAPKAN SISTEM MANAJEMEN MUTU (SMM) BERBASIS ISO 9001:2015
}

\author{
Antonius Widi Nugroho \\ SMAK St. Albertus Malang \\ Jalan Talang No. 1 Kota Malang 65112 \\ Email:widi_oc@yahoo.com
}

\begin{abstract}
This study aims to describe the application of Quality Management System (SMM) based on ISO 9001: 2015 in SMAK St. Albertus Malang. This research method using descriptive qualitative approach with research location at SMAK St. Albertus Malang. SMAK St. Albertus Malang has implemented the SMM ISO 9001: 2015 mainly on management responsibilities consisting of management commitment, customer focus, quality policy, management planning, responsibility, authority and communication and management review well. However, the implementation has not been maximized and has not referred to IWA-2 as a reference for the implementation of SMM ISO 9001: 2015 in educational institutions for more effective implementation and can meet the needs and expectations of stakeholders.
\end{abstract}

Keywords : Quality Management System (SMM), ISO 9001:2015, educational institution

Abstrak: penelitian ini bertujuan untuk mendeskripsikan penerapan Sistem Manajemen Mutu (SMM) berbasis ISO 9001:2015 di SMAK St. Albertus Malang. Metode penelitian ini menggunakan pendekatan kualitatif deskriptif dengan lokasi penelitian di SMAK St. AlbertusMalang. SMAK St. Albertus Malang telah menerapkan SMM ISO 9001:2015 terutama tentang tanggung jawab manajemen yang terdiri dari komitmen manajemen, fokus pelanggan, kebijakan mutu, perencanaan manajemen, tanggung jawab, wewenang dan komunikasi serta tinjauan manajemen dengan baik. Akan tetapi pelaksanaannya belum maksimal serta belum mengacu pada IWA-2 sebagai acuan untuk penerapan SMM ISO 9001:2015 dalam lembaga pendidikan agar pelaksanaannya lebih efektif dan dapat memenuhi kebutuhan dan harapan stakeholder.

Kata Kunci : Sistem Manajemen Mutu (SMM), ISO 9001:2015, lembaga pendidikan.

Pendidikan mempunyaiperan yang sangat penting dalam meningkatkan Sumber Daya Manusia (SDM) dan pembangunan suatu bangsa. Bertambah baiknya pengetahuan dan karakter manusia dalam suatu negara akan memberi dampak yang positif bagi perkembangan pembangunannya. Tetapi perlu kita sadari bahwa peningkatan pembangunan melalui pendidikan bukanlah suatu hal yang instan. Diperlukan suatu proses yang bertahap untuk meningkatkan pembangunan melalui pendidikan.

Pembangunan dalam bidang pendidikan yang dilaksanakan oleh pemerintah bersama masyarakat merupakan upaya untuk mewujudkan salah satu cita-cita nasional yaitu mencerdaskan kehidupan bangsa. Proses pencerdasan bangsa dilakukan baik melalui jalur sekolah maupun luar sekolah. Pada gilirannya, kesempatan memperoleh pendidikan untuk semua (education for all) semakin dirasakan masyarakat, karena pendidikan telah dijadikan sebagai kebutuhan pokok (basic need) dalam kehidupan masyarakat (Syafaruddin, 2002:1). Sayangnya menurut Otzold (dalam Sindhunata, 2000:12) menyatakan, dibandingkan dengan lembaga-lembaga yang terkait dengan bisnis dan perdagangan, sekolah termasuk lembaga yang paling rendah untuk berubah. 
PermasalahanyangdihadapibangsaIndonesia dalam hal pendidikanyaitu masih rendahnya mutu pendidikan di setiap jenjang. Departemen Pendidikan Nasional (2001:1) menjelaskan bahwa terdapat 3 faktor yang menyebabkan mutu pendidikan tidak mengalami peningkatan yaitu: (1) kebijakan dan penyelenggaraan pendidikan nasional menggunakan pendekatan education production function atau input analysis yang tidak dilaksanakan secara konsekuen. Dimana pendekatan ini kurang memperhatikan proses pendidikan. Padahal proses pendidikan menentukan output pendidikan; penyelenggaraan pendidikan dilakukan secara birokratik-sentralistik dimana bergantung pada keputusan birokrasi sehingga sekolah tidak dapat mandiri dan tidak dapat mengembangkan dan memajukan lembaganya; dan (3) kurangnya peran serta dari masyarakat.

Dengan melihat hal tersebut maka perlu adanya upaya perbaikan dan peningkatan mutu pendidikan yaitu dengan melakukan perbaikan secara berkelanjutan dalam hal proses pelaksanaan pendidikan, kemampuan Sumber Daya Manusia (SDM) dan lingkungan sekolah yaitu dengan menerapkan Sistem Manajemen Mutu (SMM) Berbasis ISO 9001:2015 yang merupakan revisi dari ISO 9001:2008. Penerapan SMM ISO 9001:2015 ini dilakukan agar manajemen sekolah bisa berjalan secara terencana dan sistematis sehingga dapat menghasilkan lulusan yang berkualitas dan tujuan pendidikan dapat tercapai secara efektif dan efisien. ISO (International Organization of Standardization) 9001 merupakan standar yang mengatur tentang sistem manajemen mutu yang diakui internasional dan 2015 adalah menunjukkan hasil revisi tahun 2015.

Penyelenggaraan pendidikan di Kota Malang pada saat ini memang terus diupayakan untuk dapat menghasilkan mutu pendidikan yang bagus mulai dari tingkat dasar sampai perguruan tinggi. SMAK St. Albertus Malang merupakan salah satu Sekolah Menengah Atas di Kota Malang yang sedang melakukan persiapan perubahan menerapkan SMM berbasis ISO 9001:2008 ke ISO 9001:2015. SMAK St. Albertus Malang mengawali dengan menerapkan ISO 9001:2000 lalu kemudian ditingkatkan menjadi ISO 9001:2008, dan sekarang ISO 9001:2015. Sertifikat ISO diperoleh dari United Registra of
Systems-United Kingdom Accreditation Service (URS-UKAS) quality management dengan nomor sertifikat 14431 .

Sistem menurut Moenir (2001:99) adalah sistem sebagai suatu susunan atau rakitan komponen atau bagian-bagian yang membentuk satu kesatuan yang utuh dengan sifat-sifat saling tergantung, saling mempengaruhi dan saling berhubungan. Sedangkan manajemen menurut Follet (dalam Handoko, 2000:8), merupakan seni dalam menyelesaikan pekerjaan melalui orang lain.

Tjiptono dan Diana (1996:55-56) mengemukakan ada dua pendapat mengenai pengertian mutu atau kualitas (quality) yaitu: dari Joseph M. Juran yang memberikan definisi, "kualitas sebagai cocok/sesuai untuk digunakan (fitness for use), bahwa suatu produk atau jasa harus dapat memenuhi apa yang diharapkan oleh para pemakainya". Philip B.Corsby yang menyatakan bahwa "mutu adalah memenuhi atau sama dengan persyaratannya (conformance to recuirments) meleset sedikit saja dari persyaratan, maka suatu produk atau jasa dikatakan tidak berkualitas". Sedangkan pengertian mutu menurut Goetsch dan Davis (2002:3) merupakan keadaan dinamik yang diasosiasikan dengan produk, jasa, orang, proses dan lingkungan yang mencapai atau melebihi harapan. Prinsip-prinsip manajemen mutu menurut Gaspersz (2002:76-83) yaitu: (1) fokus pelanggan, (2) kepemimpinan, (3) keterlibatan orang, (4) pendekatan proses, (5) pendekatan sistem, (6) peningkatan terus menerus, (7) pendekatan fakta dalam pembuatan keputusan, dan (8) hubungan pemasok yang saling menguntungkan.

Pembaharuan versi terakhir ISO 9001:2015 datang dengan fokus yang benar-benar berbeda dari versi sebelumnya yang terlalu banyak persyaratan dokumen dan form. ISO 9001:2015 tidak lagi terlalu mempersoalkan dokumen, ia fokus pada performa perusahaan dengan pendekatan pemikiran berbasis resiko (riskbasedthinking) dan konsep rencanakan-lakukanperiksa-perbaiki (Plan-Do-Check-Action) yang diterapkan di seluruh level organisasi.

Pada ISO 9001:2015, resiko dianggap sebagai suatu kesatuan yang tidak dipisahkan dari sistem. Dengan mengambil pendekatan yang berbasis resiko, organisasi diharapkan menjadi lebih proaktif ketimbang reaktif, senantiasa mencegah dan mengurangi efek yang 
tidak dikehendaki, dan selalu mempromosikan perbaikan sistem yang berkelanjutan (continoual improvement). Ketika manajemen resiko diterapkan, secara otomatis tindakan pencegahan akan dilakukan. ISO 9001:2015 mendefinisikan resiko sebagai dampak dari ketidakpastian pada hasil yang diharapkan, dengan pengertian: (1) dampak adalah penyimpangan dari yang diharapkan-positif maupun negatif; (2) resiko adalah tentang apa yang mungkin terjadi dan apa dampak yang mungkin terjadi; dan (3) risiko juga mempertimbangkan seberapa besar kemungkinannya untuk terjadi.

\section{METODE}

Penelitian ini menggunakan pendekatan kualitatif, seperti yang diungkapkan oleh Moleong (2007:11), merupakan penelitian yang bermaksud untuk memahami fenomena tentang apa yang dialami oleh subyek penelitian misalnya perilaku, persepsi, motivasi dan tindakan dengan cara deskripsi dalam bentuk kata-kata dan bahasa pada suatu konteks dengan memanfaatkan berbagai metode ilmiah.

Dalam penelitian ini, sumber data diperoleh secaralangsung di lokasipenelitian. Teknik pengumpulan data dalam penelitian ini melalui wawancara, observasi, dan dokumentasi. Lokasi dari penelitian ini adalah SMAK St. Albertus Malang. Peneliti memilih lokasi dan situs ini dikarenakan Kota Malang merupakan Kota Pendidikan. Sedangkan analisis datanya seperti yang diungkapkan oleh Miles dan Huberman (dalam Sugiyono, 2015:246) yaitu pengumpulan data, reduksi data, penyajian data, dan penarikan kesimpulan atau verifikasi.

\section{HASIL}

SMAK St. Albertus Malang telah menerapkan Sistem Manajemen Mutu ISO 9001:2015 untuk menyempurnakan sistem manajemen sekolah dengan melakukan perbaikan secara berkelanjutan. SMAK St. Albertus Malang memiliki komitmen dalam memenuhi harapan pelanggan dengan menetapkan kebijakan mutu, sasaran mutu, dan mengadakan rapat tinjauan manajemen. SMAK St. Albertus Malang telah berupaya mencapai kepuasan pelanggan yaitu dengan melakukan perbaikan sarana dan prasarana dalam proses belajar mengajar, perbaikan infrastruktur lingkungan sekolah, peningkatan akademik dan peningkatan UKS. SMAK St. Albertus Malang mempunyai sasaran dan kebijakan mutu sebagai acuan dalam berbagai pengambilan keputusan agar visi dan pemenuhan kebutuhan pelanggan dapat tercapai. SMAK St. Albertus Malang telah menetapkan tanggung jawab dan wewenang untuk masing-masing personal yang saling terkait dan saling berpengauruh terhadap Sistem Manajemen Mutu serta menetapkan media komunikasi internal untuk menunjang kelancaran pelaksanaan Sistem Manajemen Mutu ISO 9001:2015. SMAK St. Albertus Malang juga telah melakukan tinjauan manajemen setiap 6 bulan sekali untuk memastikan Sistem Manajemen Mutu diterapkan secara efektif serta bermanfaat bagi sekolah untuk menjaga konsistensinya terhadap efisiensi yang harus dipertahankan.

\section{PEMBAHASAN}

Sistem Manajemen Mutu berbasis ISO 9001:2015 dibuat untuk mengatur manajemen dalam sebuah organisasi agar lebih terencana dan sistematis agar dapat memenuhi apa saja yang diharapkan oleh pelanggan secara efektif dengan melakukan perbaikan secara terus menerus (continual improvement). Seperti pada tujuan SMAK St. Albertus Malang menerapkan SMM ISO 9001:2015 yaitu antara lain: (1) menyempurnakan sistem manajemen sekolah yang berbasis SMM; (2) upaya sekolah untuk melakukan continual improvement di segala bidang melalui sekolah yang berstandar internasional; dan (3) sekolah harus mencapai dan mempertahankan kualitas layanan yang dihasilkan, sehingga secara berkesinambungandapat memenuhi kebutuhan para pengguna (costumer).

Menurut Gaspersz (2002:25) terdapat 7 klausul yang harus dilaksanakan oleh organisasi yang menerapkan SMM ISO 9001:2015. SMAK St. Albertus Malang telah melaksanakan poin-poin yang ada dalam klausul, antara lain komitmen manajemen, fokus pada pelanggan, kebijakan mutu, perencanaan manajemen, tanggung jawab, wewenang dan komunikasi serta tinjauan manajemen. 
SMAK St. Albertus Malang memiliki komitmen untuk mengembangkan, menerapkan dan meningkatkan Sistem Manajemen Mutu dengan cara kepala sekolah mengkomunikasikan penerapan Sistem Manajemen Mutu kepada seluruh jajaran dengan menetapkan kebijakan mutu dan sasaran mutu, menetapkan tanggung jawab dan wewenang dan mengadakan rapat tinjauan manajemen. SMAK St. Albertus Malang selalu berupaya untuk fokus pada pelanggan, yang dimaksud pelanggan disini adalah siswa, dengan memenuhi kebutuhan dan harapan pelanggan yaitu dengan melakukan perubahan secara terus menerus di seluruh bidang antara lain dengan melakukan perbaikan sarana dan prasarana proses belajar mengajar, perbaikan insfrastruktur lingkungan sekolah, peningkatan akademik dengan program akselerasi dan olimpiade, perbaikan sarana dan prasarana ekstrakurikuler, perbaikan sarana ibadah, peningkatan perpustakaan untuk menunjang proses pembelajaran dan peningkatan UKS untuk memberikan pelayanan kesehatan yang lebih baik kepada warga sekolah.

Konsep semacam ini, sebetulnya sudah sering ditemukan dalam ISO 9001:2008 dalam prinsip PDCA (Plan - Do -Check - Action). Hanya saja memang, ISO 9001:2008 tidak secara spesifik mengatur tentang manajemen resiko.
Berikut ini perubahan atau perbedaan utama ISO 9001:2015 dan ISO 9001:2008 berdasarkan aspek atau komponennya.

1. Klausul Bertambah

ISO 9001:2008 memiliki 8 klausul sedangkan ISO 9001:2015 memiliki 10 klausul. Bila diperhatikan, struktur klausul ISO 9001:2015 lebih rapi karena telah dikelompokkan dengan baik. Berikut perbandingannya:

Tabel 1 Perbedaan Struktur Klausul

\begin{tabular}{|c|c|}
\hline ISO 9001:2008 & ISO 9001:2015 \\
\hline 1. Scope & 1. Scope \\
\hline $\begin{array}{l}\text { 2.Normative } \\
\text { References }\end{array}$ & $\begin{array}{l}\text { 2. Normative } \\
\text { references }\end{array}$ \\
\hline $\begin{array}{l}\text { 3. Terms and } \\
\text { definitions }\end{array}$ & $\begin{array}{l}\text { 3. Terms and } \\
\text { definitions }\end{array}$ \\
\hline $\begin{array}{l}\text { 4. Quality management } \\
\text { system }\end{array}$ & $\begin{array}{l}\text { 4. Context of the } \\
\text { organization }\end{array}$ \\
\hline $\begin{array}{l}\text { 5. Management } \\
\text { responbility }\end{array}$ & 5. Leadership \\
\hline $\begin{array}{l}\text { 6. Resource } \\
\text { management }\end{array}$ & 6. Planning \\
\hline 7. Product realization & 7. Support \\
\hline \multirow{3}{*}{$\begin{array}{l}\text { 8. Measurement, } \\
\text { analysis, and } \\
\text { improvement }\end{array}$} & 8. Operation \\
\hline & $\begin{array}{l}\text { 9. Performance } \\
\text { evaluation }\end{array}$ \\
\hline & 10. Improvement \\
\hline
\end{tabular}

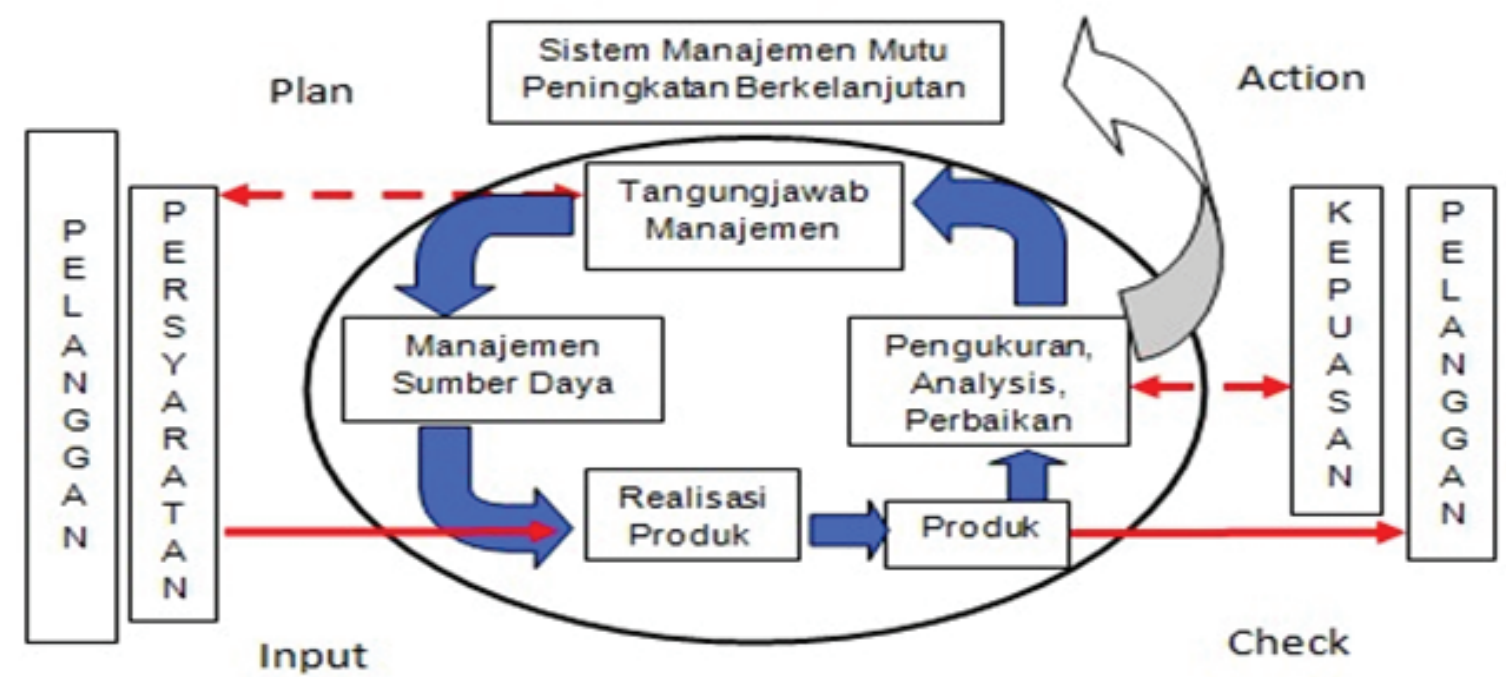

Gambar 1. Model Sistem ManajemenMutu PDCA 


\section{Prinsip ISO 9001 Berkurang}

ISO 9001:2008 memiliki 8 prinsip, adapun ISO 9001:2015 memiliki 7 prinsip. Berikut perbandingan 8 prinsip IS0 9001:2008 dengan 7 prinsip ISO 9001:2015.

\section{Tabel 2 Perbandingan Prinsip}

\begin{tabular}{|c|c|}
\hline ISO 9001:2008 & ISO 9001:2015 \\
\hline 1. Customer focus & 1. Customer focus \\
\hline 2. Leadership & 2. Leadership \\
\hline $\begin{array}{l}\text { 3. Involvement of } \\
\text { people }\end{array}$ & $\begin{array}{l}\text { 3. Engagement and } \\
\text { competence of people }\end{array}$ \\
\hline 4. Proses pendekatan & 4. Processs approach \\
\hline $\begin{array}{l}\text { 5. System approach to } \\
\text { management }\end{array}$ & 5. Improvement \\
\hline $\begin{array}{l}\text { 6. Continual } \\
\text { improvement }\end{array}$ & $\begin{array}{l}\text { 6. Informed decision } \\
\text { making }\end{array}$ \\
\hline $\begin{array}{l}\text { 7. Factual approach to } \\
\text { decision making }\end{array}$ & $\begin{array}{l}\text { 7. Relationship } \\
\text { management }\end{array}$ \\
\hline $\begin{array}{l}\text { 8. Mutually beneficial } \\
\text { supplier relationships }\end{array}$ & \\
\hline
\end{tabular}

\section{Istilah baru untuk dokumen}

ISO 9001:2008, dibedakan antara dokumen mutu (documents) dan rekaman mutu (records). Pada ISO 9001:2015 keduanya disebut sebagai informasi terdokumentasi (documented information). Dengan penggabungan istilah ini, organisasi diberikan kebebasan dalam menentukan informasi terdokumentasi yang dibutuhkan. Tidak lagi dipersyaratkan harus dalam bentuk prosedur (seperti 6 prosedur wajib).

\section{Tidak Ada Prosedur Wajib}

ISO 9001:2015 sepertinya berupaya untuk menghilangkan kesan bahwa penerapan ISO 9001 hanya bertumpu pada pembuatan SOP atau prosedur saja. ISO 9001:2015 tidak lagi terlalu mementingkan dokumen. ISO 9001:2015 berorientasi kepada proses. Meskipun, keberadaan sistem dokumentasi tetap diperlukan. Hanya saja disederhanakan menjadi "Informasi terdokumentasi".

\section{Manual Mutu Tidak Wajib}

Banyak yang merasa manual mutu hanyalah dokumen formalitas yang tidak memberi manfaat tambahan. Oleh karena itu, keberadaan manual mutu di ISO 9001:2015 tidak wajib. Ini bukan berarti manual mutu yang sudah dibuat harus dihapus, masih boleh menggunakannya bila dibutuhkan.
6. Management Representative Tidak Harus Ada

ISO 9001:2015 tidak mewajibkan keberadaan management representative yang harus ditunjuk secara resmi. Ini bisa jadi agar penerapan ISO 9001 diharapkan tidak hanya bertumpu pada seorang penanggug jawab saja. Setiap orang, khususnya penanggung jawab dari setiap bagian/divisi/departemen memiliki tugas dan tanggung jawab yang sama dalam penerapan sistem manajemen mutu ISO 9001:2015

7. Tidak ada pengecualian klausul (exclution)

ISO 9001:2008 membolehkan pengecualian salah satu dari klausul atau subklausul 7 bila ada peraturan yang tidak relevan. Tidak ada satupun klausul ISO 9001:2015 yang secara tegas menjelaskan tentang kebolehan mengecualikan salah satu klausul ISO 9001:2015.

8. Mengganti Istilah Preventive Action dengan Risk Management

Ini salah satu unsur perubahan yang paling signifikan dari ISO 9001:2015. Istilah tindakan pencegahan kini diganti dengan cakupan yang lebih luas, yaitu manajemen resiko.

\section{Membedakan Istilah Produk dan Jasa}

Produk menurut ISO 9001:2008 bisa berupa barang dan jasa sebagaimana yang tercantum pada klausul 3 mengenai Istilah dan Definisi: Bila di seluruh naskah Standar Internasional ini di temukan istilah "produk", ia dapat juga berarti "jasa". Pada versi ISO 9001:2015, keduanya dibedakan untuk memberikan batasan yang jelas antara barangdengan jasa.

\section{Mengganti beberapa Istilah}

Ada beberapa istilah yang diganti pada versi ISO 9001:20015. Diantaranya: (1) "supplier"diganti dengan"external provider"; (2) "Purchased Product"diganti dengan"Externally provided products and services"; dan (3) "Work Environment"diganti dengan"Environment for the operation of the process"

Bila dilihat, perubahan istilah tersebut bertujuan agar istilah yang digunakan tidak terkesan hanya berkaitan dengan barang saja tetapi juga termasuk jasa. Perubahan istilah ini bukan berarti perusahaan yang telah menerapkan ISO 9001:2008 wajib mengganti istilah yang ada. Is- 
tilah yang sudah ada masih bisa digunakan sesuai kebutuhan

Manfaat dari implementasi ISO 9001:2015 dapat terbagi menjadi 3 bagian, sesuai dengan stakeholder dan target dari penggunaannya, seperti pada Tabel 3.
(5) mendefinisikan struktur organisasi dan tanggung jawab; (6) menciptakan kesadaran mutu (quality awareness) pada semua tingkat dalam organisasi; (7) mengembangkan peninjauan ulang dari sistem manajemen mutu dalam manual (buku panduan) mutu; (8) menyepakati

\begin{tabular}{ll}
\hline Manfaat & Proses Pencapaian \\
\hline $\begin{array}{l}\text { Peningkatan efisiensi } \\
\text { tingkat operasional }\end{array}$ & $\begin{array}{l}\text { Proses serta dokumentasi yang ditetapkan secara efektif menyebabkan pekerjaan } \\
\text { dapat dilakukan secara konsisten, variasi yang tidak memenuhi standar mutu dapat } \\
\text { diminimalkan dan tingkat kesalahan dapat dihindarkan. }\end{array}$ \\
$\begin{array}{l}\text { Peningkatan efisiensi } \\
\text { tingkat organisasi }\end{array}$ & $\begin{array}{l}\text { Implementasi proses tindakan perbaikan dan pencegahan secara efektif } \\
\text { menyebabkan solusi permanen terhadap permasalahan dapat diterapkan. Pekerjaan } \\
\text { ulang dan waste diminimalkan. }\end{array}$ \\
Peningkatan & $\begin{array}{l}\text { ISO 9001:2015 menekankan peningkatan berkelanjutan. Kinerja direview secara } \\
\text { produktivitas }\end{array}$ \\
$\begin{array}{l}\text { teratur dan fokus pada pencapaian target. } \\
\text { proses secara terus } \\
\text { menerus. }\end{array}$ & $\begin{array}{l}\text { Penerapan pendekatan proses secara efektif akan menyebabkan organisasi fokus } \\
\text { pada proses bisnis. ISO 9001:2015 mempersyaratkan proses pemantauan dan }\end{array}$ \\
Kepercayaan konsumen, \\
pengukuran kinerja proses dilakukan secara terus menerus. \\
$\begin{array}{l}\text { Implementasi dan sertifikasi ISO 9001:2015 menyebabkan penilaian positif } \\
\text { organisasi dalam } \\
\text { persaingan di pasar }\end{array}$ & $\begin{array}{l}\text { proses bisnis yang focus pada pelanggan, memahami kebutuhan pelanggan dan } \\
\text { meningkatkan kepuasan pelanggan. }\end{array}$ \\
\hline
\end{tabular}

\section{Tabel 3 Manfaat Bagi Organisasi}

Tujuan ISO menurut Gaspersz (2002: 177) adalah mengembangkan standarisasi dan kegiatan-kegiatan yang lain yang berhubungan untuk memudahkan pertukaran barang dan jasa, serta mengembangkan kerjasama dalam suasana yang bersifat scientifik, teknologis dan ekonomis. Penerapan suatu proses dalam suatu organisasi biasanya memiliki beberapa langkah, untuk kasus penerapan sistem manajemen mutu menurut Gasperz (2002:10) urutan-urutan yang diberikan hanya merupakan suatu petunjuk, yang dapat saja dilakukan bersamaan atau dalam susunan yang tidak harus berurut, tergantung pada kultur dan kematangan organisasi, tetapi semua langkah ini harus diperhatikan secara serius dan konsisten. Langkah-langkahnya sebagai berikut: memutuskan untuk mengadopsi suatu standar system manajemen mutu yang diterapkan, yaitu: (1) menetapkan suatu komitmen pada tingkat pemimpin senior dari organisasi (top management commitment); (2) menetapkan suatu kelompok kerja (working group) atau komite pengarah (steering committee) yang terdiri dari manajermanajer senior; (3) menetapkan tujuan-tujuan mutu dan implementasi sistem; (4) meninjau ulang sistem manejemen mutu yang sekarang; bahwa fungsi-fungsi dan aktivitas dikendalikan oleh prosedur-prosedur; (9) mendokumentasikan aktivitas terperinci dalam prosedur operasional atau prosedur terperinci; (10) memperkenalkan dokumentasi, sekali manual mutu dan prosedurprosedur telah disepakati, maka implementasi dari praktik-praktik sistem manajemen mutu pada tingkat manajemen dapatdilakukan; (11) menetapkan partisipasi karyawan dan pelatihan dalam sistem; dan (12) meninjau ulang dan melakukan audit sistem manajemen mutu.

SMAK St. Albertus Malang menetapkan kebijakan mutu dimana kebijakan mutu ini dibuat oleh kepala sekolah dalam upaya mencapai visi sekolah dan sebagai acuan kerja pada seluruh Sumber Daya Manusia di sekolah. Kebijakan mutu ini diterapkan secara berkelanjutan. Kebijakan mutu SMAK St. Albertus Malang yaitu, SMA Katolik St. Albertus Malang berkomitmen untuk meningkatkan mutu pendidikan dengan memperhatikan nilai-nilai pendidikan: pembentukan karakter, penanaman nilai serta pengembangan iman dalam semangat doa, persaudaraan, dan pelayanan sehingga dapat mewujudkan visi SMA Katolik St. Albertus menjadikan siswa-siswa sebagai insan yang cendekia, berhati dan berbakti kepada bangsa dan negara. 
Tabel 4 Manfaat Bagi Karyawan

\begin{tabular}{ll}
\hline Manfaat & Proses Pencapaian \\
\hline $\begin{array}{l}\text { Meningkatnya kepuasan } \\
\text { karyawan dalam bekerja }\end{array}$ & $\begin{array}{l}\text { Proses bisnis yang sistematis akan menuntun karyawan bekerja secara } \\
\text { sistematis pula. Tingkat stress karyawan yang diakibatkan oleh ketidakjelasan } \\
\text { dengan tidak adanya sistem yang mendukung mereka bekerja diminimalkan. }\end{array}$ \\
$\begin{array}{l}\text { Meningkatnya kebanggaan } \\
\text { terhadap perusahaan }\end{array}$ & $\begin{array}{l}\text { Sertifikasi yang diperoleh dari implementasi akan memberikan dampak positif } \\
\text { terhadap rasa memiliki dari karyawan terhadap perusahaan. }\end{array}$ \\
$\begin{array}{l}\text { Timbulnya proses } \\
\text { pembelajaran bagi }\end{array}$ & $\begin{array}{l}\text { Prosedur terdokumentasi, instruksi kerja yang informatif, alur kerja yang jelas } \\
\text { memberikan kesempatan bagi karyawan baru untuk secara cepat beradaptasi }\end{array}$ \\
\hline
\end{tabular}

Tabel 5 Manfaat Bagi Konsumen

\begin{tabular}{ll}
\hline Manfaat & Proses Pencapaian \\
\hline $\begin{array}{l}\text { Produk dan jasa bermutu } \\
\text { sesuai dengan harapan } \\
\text { konsumen }\end{array}$ & $\begin{array}{l}\text { Kesinambungan implementasi akan meningkatkan kemampuan perusahaan } \\
\text { lebih fokus pada pelanggan. Perusahaan akan berorientasi pada keberhasilan } \\
\text { dalam pemenuhan harapan konsumen secara lebih efektif. Identifikasi harapan } \\
\text { konsumen dapat dilakukan secara sistematis, serta digunakan masukan dalam } \\
\text { sasaran dan proses bisnis ditingkatkan untuk mendukung sasaran tersebut. }\end{array}$ \\
$\begin{array}{l}\text { Meningkatnya kepuasan } \\
\text { pelanggan }\end{array}$ & $\begin{array}{l}\text { ISO 9001:2015 memuat persyaratan bagaimana keluhan pelanggan } \\
\text { ditindaklanjuti secara efektif. Ketidakpuasan pelanggan di masa mendatang } \\
\text { Selalu diupayakan dapat diminimalkan. }\end{array}$ \\
$\begin{array}{l}\text { Kepercayaan yang tinggi, } \\
\text { risiko transaksi yang rendah }\end{array}$ & $\begin{array}{l}\text { Sertifikasi ISO 9001:2015 merupakan salah satu sarana bagi perusahaan } \\
\text { untuk menanamkan kepercayaan dan reputasi yang tinggi bagi pelanggan. } \\
\text { Pengelolaan proses-proses sistem manajemen yang efektif menghasilkan } \\
\text { masalah terhadap kualitas tidak ditentukan oleh pelanggan, namun telah } \\
\text { dikendalikan secara efektif oleh perusahaan. }\end{array}$ \\
\hline
\end{tabular}

SMAK St. Albertus Malang mempunyai sasaran-sasaran mutu dalam rangka untuk mencapai tujuan sekolah dan untuk perbaikan secara terus menerus yaitu: (1) peningkatan nilai ujian nasional; (2) peningkatan jumlah lulusan $100 \%$; (3) encapaian kepuasan pelayanan sekolah; (4) pemenuhan rencana penelitian dan kerja sama dalam bidang karya ilmiah; (5) peningkatan kedisiplinan kehadiran guru; (6) peningkatan kedisiplinan siswa; dan(7) peningkatan prestasi akademik di bidang olimpiade sains, TIK, Astronomi, Geologi, dan Ekonomi.

SMAK St. Albertus Malang menetapkan tugas, tanggung jawab, wewenang dan kualifikasi untuk masing-masing personal yang menangani ISO 9001:2015 (Management Representative, Auditor dan Document Control) yang saling terkait dan saling berpengaruh satu sama lain agar pelaksanaan penerapan ISO 9001:2015 dapat berjalan secara efektif. Selain itu juga menetapkan proses komunikasi dimana komunikasi tersebut dapat mendukung efektifitas SMM yaitu melalui papan pengumuman, surat keputusan, dan rapat rutin mingguan. SMAK St. Albertus Malang melaksanakan rapat tinjauan manajemen setiap 6 bulan sekali untuk memastikan kesesuaian, kecukupan dan efektifitasnya serta mengevaluasi keperluan untuk perbaikan Sistem Manajemen Mutu. Rapat ini membahas hasil dari audit internal dan eksternal.

Seperti yang dijelaskan dalam salah satu prinsip Sistem Manajemen Mutu yang bahwa terapkan PDCA dalam setiap tindakan. Pengendalian dan perbaikan mutu merupakan kegiatan yang berkelanjutan yang harus dijalankan secara sistematis dengan menerapkan pendekatan manajemen Plan, Do, Check and Action (PDCA) dari setiap karakteristik. Jika dihubungkan dengan pendekatan PDCA tersebut maka tanggung jawab manajemen merupakan bagian dari proses perencanaan (plan), dimana yang dimaksud dalam plan disini adalah rencana proses mutu yang berorinetasi pada kebutuhan pelanggan (Widodo, 2011:12).

Dalam implementasi SMM ISO 9001:2015 di SMAK St. Albertus Malang terdapat faktor- 
faktor pendukung dan penghambat. Adapun faktor-faktor yang mendukung implementasi SMM ISO 9001:2015 di SMAK St. Albertus Malang antara lain: (1) Adanya penetapan tugastugas yang harus dilaksanakan oleh koordinator tiap-tiap bagian sehingga mereka mengetahui apa saja yang harus dilakukan tanpa menunggu komando dari kepala sekolah. Penetapan tugastugas ini ditetapkan pada awal tahun ajaran; dan(2) SMAK St. Albertus Malang merupakan sekolah swasta. Dimana sekolah swasta harus tertata dengan baik dan menjaga kualitas agar menarik minat peserta didik melanjutkan sekolah ke SMAK St. Albertus Malang. Hasil penelitian Triwiyanto (2013:125) memperlihatkan bahwa saat ini terdapat hampir 50 persen sekolah disemua jenjang belum memenuhi standar pendidikan minimal. Artinya, masih banyak sekolah yang harus diperbaiki mutu layanan pendidikannya. Padahal beban tersebut harus ditambah dengan sekolah yang masih berada di standar minimal, yang tentu saja belum optimal mutu layanan pendidikannya.

Sedangkan faktor-faktor yang menghambat implementasi SMM ISO 9001:2015 di SMAK St. Albertus Malang antara lain: (1) belum maksimalnya masing-masing personal yang menangani ISO dalam menjalankan tugasnya yang telah ditetapkan; (2) dengan melihat hasil tim audit internal maka dapat dikatakan bahwa SMAK St. Albertus Malang masih belum menjalankan SMM ISO 9001:2015 secara maksimal karena masih banyaknya ditemukan ketidaksesuaian. Yang dimaksud dengan ketidaksesuaian disini adalah ketidakmampuan dalam memenuhi persyaratan/klausul dalam ISO 9001:2015; (3) belum maksimalnya dalam hal pembahasan yang dilakukan dalam rapat tinjauan manajemen dimana hanya membahas hasil audit internal dan eksternal; (4) kurangnya pengetahuan tentang IWA-2, dimana IWA-2 merupakan panduan penerapan SMM ISO 9001:2015 bagi lembaga pendidikan sehingga diharapkan sekolah lebih efektif dalam memenuhi harapan pelanggan; dan (5) tidak adanya unit kerja khusus yang menangani Sistem Manajemen Mutu ISO 9001:2015.

\section{KESIMPULAN DAN SARAN}

\section{Kesimpulan}

SMAK St. Albertus Malang telah menerapkan SMM ISO 9001:2015 terutama tentang tanggung jawab manajemen yang terdiri dari komitmen manajemen, fokus pelanggan, kebijakan mutu, perencanaan manajemen, tanggung jawab, wewenang dan komunikasi serta tinjauan manajemen dengan baik. Akan tetapi pelaksanaannya belum maksimal serta belum mengacu pada IWA-2 sebagai acuan untuk penerapan SMM ISO 9001:2015 dalam lembaga pendidikan agar pelaksanaannya lebih efektif dan dapat memenuhi kebutuhan dan harapan stakeholder.

\section{Saran}

Saran demi menuju pada perbaikan dan kesempurnaan dalam penerapan Sistem Manajemen Mutu ISO 9001:2015 di SMAK St. Albertus Malang yaitu: (1) sebaiknya dilakukan sosialisasi tentang pemahaman Sistem Manajemen Mutu ISO 9001:2015 kepada semua stakeholder yang ada di SMAK St. Albertus Malang sehingga tidak hanya tim ISO yang memahami Sistem Manajemen Mutu ISO 9001:2015. Hal ini bertujuan untuk menunjang keberhasilan pelaksanaan Sistem Manajemen Mutu ISO 9001:2015 di SMAK St. Albertus Malang; (2) dalam hal proses audit internal sebaiknya SMAK St. Albertus Malang menetapkan anggota auditor lebih banyak lagi agar pelaksanaan audit internal dapat berjalan secara efektif dan lebih maksimal; (3) dalam hal kerja sama lebih diefektifkan lagi antar bagian satu dengan bagian lainnya untuk menunjang keberhasilan pelaksanaan Sistem Manajemen Mutu ISO 9001:2015; (4) dari pengamatan peneliti di lapangan, dalam hal tinjauan manajemen, SMAK St. AlbertusMalang melaksananakan rapat tinjauan manajemen yang hanya membahas audit internal dan eksternal. Seharusnya di dalam rapat tinjauan manajemen juga dibahas masalah keluhan dari siswa dimana penerapan SMM ISO 9001:2015 ini bertujuan untuk memenuhi kebutuhan yang diharapkan siswa; (5) dalam mengembangkan Sistem Manajemen Mutu ISO 9001:2015 ini sebaiknya SMAK St. Albertus Malang dapat membentuk unit kerja khusus yang menangani Sistem Manajemen Mutu agar 
pelaksanaan Sistem Manajemen ISO 9001:2015 dapat berjalan dengan lancar; dan (6) diharapkan SMAK St. Albertus Malang untuk berpedoman pada IWA-2 dimana dengan berpedoman pada IWA-2 lembaga pendidikan memiliki efektifitas yang lebih tinggi dalam pemenuhan harapan pelanggan.

\section{DAFTAR RUJUKAN}

Departemen Pendidikan Nasional. 2001.Manajemen Peningkatan Mutu Berbasis Sekolah. Direktorat Jenderal Pendidikan Dasar dan Menengah. Jakarta: Departemen Pendidikan Nasional

Gaspersz, Vincent. 2002.ISO 9001:2000 and Continual Quality Improvement. Jakarta: Gramedia Pustaka.

Goetsch D.L \& Davis D.L. 2002.Introduction to Total Quality: Quality Management for Production, Process, and Service. Edisi Terjemahan. Alih Bahasa oleh Benyamin Molan. Manajemen Mutu Total: Manajemen Mutu untuk Produksi, Pengelolaan dan Pelayanan.Jilid 1. Jakarta: PT Prenhalindo.
Handoko, T Hani. 2000.Manajemen. Yogyakarta: BPFE.

Moenir, H.A.S. 2001.Manajemen Pelayanan Umum di Indonesia. Jakarta: Bumi Aksara.

Moleong, Lexy J. 2007.Metodelogi Penelitian Kualitatif. Bandung: PT Remaja Rosada Karya.

Sindhunata, GP, Dr, SJ. 2000.Menggagas Paradigma Baru Pendidikan, Demokratis, Otonomi, Civil Society, Globalisasi. Jakarta: Kanisius.

Sugiyono. 2015.Metode Penelitian Kuantitaif Kualitatif dan R\&D. Bandung: Alfabeta.

Syafaruddin. 2002.Manajemen Mutu Terpadu dalam Pendidikan. Jakarta: Grasindo.

Tjiptono, F. dan Diana, A. 1996.Total Quality Management. Yogyakarta: ANDI.

Triwiyanto, T. 2013. Pemetaan Mutu Manajemen Berbasis Sekolah Melalui Audit Manajemen Pendidikan. Jurnal Manajemen Pendidikan. 24 (2): 125-134.

Widodo, Suparno Eko. 2011.Manajemen Mutu Pendidikan. Jakarta: Ardadizya Jaya. 